\title{
SISTEM MANAJEMEN MUTU ISO 9000 DALAM PENINGKATAN MUTU PRODUK DAN PELAYANAN SERTA KEPUASAN PELANGGAN DI PASAR INTERNASIONAL
}

\section{ISO 9000 QUALITY MANAGEMENT SYSTEM IN IMPROVING PRODUCT QUALITY AND SERVICE AND CUSTOMER SATISFACTION IN THE INTERNATIONAL MARKET}

\author{
Dian Fitri ${ }^{1}$, Widodo Ismanto ${ }^{2}$ \\ Program Studi Magister Manajemen Program Pascasarjana Universitas Riau Kepulauan \\ dianbatamania@gmail.com
}

\begin{abstract}
Abstrak
Sistem Manajemen Mutu ISO seri 9000 Dalam Peningkatan Mutu Produk dan Pelayanan Indonesia serta Kepuasan di Pasar Internasional. Tujuan dari penulisan skripsi ini adalah untuk menggambarkan serta mengetahui Sistem Manajemen Mutu ISO seri 9000 dalam peningkatan mutu Produk Indonesia di Pasar Internasional. Fokus penelitian yang diangkat mengenai Respon Indonesia terhadap Pemberlakuan Sistem Manajemen Mutu ISO seri 9000 di pasar Internasional. Indonesia menetapkan suatu komitmen Inlooking Policy dan Outlooking Policy untuk meningkatkan Kualitas Produk dan Pelayanan sehingga Produk Eksport kita dapat di terima di kancah internasional. Teknik pengumpulan data dilakukan dengan cara penelitian kepustakaan dan dokumentasi, Jenis penelitian yang digunakan adalah deskriptif dan akan dianalisis secara kualitatif. Dari hasil penelitian diketahui bahwa Sistem Manajemen Mutu dalam peningkatan mutu Produk dan Pelayanan dan kepuasan pelanggan di Pasar Internasional.
\end{abstract}

\section{Kata Kunci: Sistem Manajemen Mutu, ISO 9000, Kepuasan Pelanggan}

\begin{abstract}
ISO 9000 series Quality Management System in Improving Indonesian Product and Service Quality and Satisfaction in International Markets. The purpose of this paper is to describe and find out the ISO 9000 series Quality Management System in improving the quality of Indonesian Products in the International Market. The focus of the research was raised on Indonesia's Response to the Implementation of the 9000 series ISO Quality Management System in the international market. Indonesia established an Inlooking Policy and Outlooking Policy commitment to improve the Quality of Products and Services so that our Export Products could be received internationally. Data collection techniques are carried out by means of library research and documentation. The type of research used is descriptive and will be analyzed qualitatively. From the results of the study it is known that the Quality Management System in improving product quality and service and customer satisfaction in the International Market.
\end{abstract}

Keywords: Quality Management System, ISO 9000, Customer Satisfaction

\section{PENDAHULUAN}

Setiap organisasi yang baik tentu memiliki tujuan dan sasaran yang dituangkan dalam sistem manajemen mutu yang pada dasarnya mengarah pada pemenuhan kebutuhan pelanggan atau masyarakat. Untuk mencapai tujuan dan sasaran yang telah ditetapkan tersebut, manajemen setiap organisasi tentu saja memiliki acuan tersendiri untuk menyusun Sistem Manajemen Mutu yang akan diterapkan dalam pelaksanaan proses sehari-hari organisasi. Berbagai upaya dilakukan oleh organisasi untuk memenuhi kebutuhan dan kepuasaan pelanggan, antara lain, dengan penerapan Sistem Manajemen Mutu yang efektif 
serta dengan perbaikan terus-menerus agar mampu memenuhi keinginan serta pelayanan yang baik bagi pelanggan. Untuk dapat menerapkan upaya perbaikan terus-menerus, organisasi harus mampu mengukur dan mengontrol manajemen mutunya. Itulah sebabnya diperlukan standar yang bersifat lokal, nasional, maupun internasional.

Internasional Standard Organisation atau lebih dikenal dengan ISO adalah organisasi internasional yang bertanggung jawab dalam mengoordinasikan penyusunan standar baru ataupun revisi ISO standar yang telah ada. ISO membawahi sejumlah Badan Sertifikasi Nasional yang terdiri dari 135 Negara atau lebih diseluruh dunia.

Pada umumnya, ISO terkait dengan produk maupun jasa. Standarstandar yang telah ditetapkan akan ditinjau kembali dalam jangka waktu 5-6 tahun untuk memastikan standar tersebut masih relevan dengan perkembangan dunia industri dan jasa. ISO yang banyak digunakan adalah ISO seri 9000 yang merupakan persyaratan yang digunakan dalam penerapan Sistem Manajemen Mutu suatu organisasi. ISO seri 9000 bukan merupakan standar produk, tetapi merupakan standar dari sistem manajemen suatu organisasi yang apabila diterapkan dalam organisasi tersebut akan memengaruhi bagaimana produk itu dihasilkan.

ISO seri 9000 memiliki 4 seri, yaitu ISO 9000, ISO 9001, ISO 9004 dan ISO 19011. ISO 9001 merupakan standar yang diterbitkan oleh organisasi internasional untuk standar yang berisi persyaratan manajemen mutu. ISO 9001 telah mengalami beberapa kali perubahan. Perubahan pertama pada tahun 1987, kemudian pada 1994 dan yang ketiga pada 2000. ISO merilis edisi terbaru standar ISO 9001, yaitu ISO 9001, Quality Management System Requirements.

Standar Sistem Manajemen Mutu ISO seri 9000 berisi persyaratan yang lebih menekankan pada pendekatan proses, hal ini bertujuan untuk menjamin bahwa organisasi akan memberikan produk (barang dan/atau jasa) yang memenuhi persyaratan yang ditetapkan. Persyaratan-persyaratan yang ditetapkan ini dalam rangka menjawab kebutuhan spesifik dari pelanggan, dimana organisasi yang menerapkan Sistem Manajemen Mutu ISO 9001 harus dapat menjamin kualitas dari produk tetentu atau merupakan kebutuhan dari pasar tertentu sebagaimana yang ditentukan oleh organisasi.

Di dalam Sistem Manajemen Mutu ISO 9001 itu sendiri harus mampu menyediakan bukti objektif bahwa sistem manajemen mutu telah ditetapkan secara efektif dan analisis dari proses menjadi sumber dalam menetapkan dokumen yang diperlukan untuk memenuhi 
persyaratan Sistem Manajemen Mutu ISO 9001. Pemenuhan persyaratan yang dimaksud adalah pemenuhan terhadap prinsip-prinsip manajemen ISO 9001 untuk memenuhi kepuasaan pelanggan. Prinsip-prinsip manajemen ISO 9001 adalah perhatian pada pelanggan,kepemimpinan, pelibatan orang, pendekatan proses, pendekatan sistem pada manajemen, perbaikan berkelanjutan, pengambilan keputusan berdasarkan fakta, dan hubungan pemasok yang saling menguntungkan.

Beberapa Kasus di Negara - Negara yang menolak Produk Indonesia:

1. Jepang menolak masuknya pucuk tebu asal Indonesia dengan alasan PMK Penyakit Mulut dan Kuku kasus di Indonesia mengadu kepada SPS WTO karena Indonesia dalam daftar OIE yang merupakan salah satu negara dinyatakan bebas dari PMK saat ini .

2. Di Malaysia melalui Institusi karantina menerapkan ketentuan yang melarang cocoa pods, rambutan,nanas, pulasan dan Logam dari Indonesia dengan alasan penyakit tetapi Malaysia tidak mencantumkan/ menjelaskan jenis jenis penyakitnya.

3. Australia mengenakan penundaan pesanan (holding order) terhadap beberapa produk hasil pertanian dengan alasan residu logam berat dan antibiotik, food additive, kontaminasi mikrobiologi dan aflatoksin serta alasan perlindungan kesehatan konsumen

\section{Kerangka Dasar Teori}

\section{Sistem}

Menurut Campbell dalam Rahman (2010), sistem adalah himpunan komponen atau bagian yang saling berkaitan yang bersama-sama berfungsi untuk mencapai sesuatu tujuan. Award dalam Rahman (2010), lebih menekankan memasukkan unsur rencana kedalamnya, sehingga sistem adalah sehimpunan komponen atau subsistem yang terorganisasikan dan berkaitan sesuai dengan rencana untuk mencapai sesuatu tujuan tertentu.

Konontz dan O’Donnell dalam Rahman (2010), sistem adalah bukan wujud fisik, melainkan ilmu pengetahuan juga disebut sebagai suatu sistem yang terdiri dari fakta, prinsip, doktrin dan sejenisnya.

\section{Manajemen}

Menurut Allen dalam Herujito (2011) manajemen adalah suatu jenis pekerjaan khusus yang menghendaki usaha mental dan fisik yang diperlukan untuk memimpin, merencana, menyusun, dan mengawasi. 


\section{Mutu}

Fred Smith, CEO dari Federal Express dalam Goetsch dan Davis (1997) mendefinisikan mutu sebagai kinerja sesuai standar yang diharapkan oleh pelanggan. GSA dalam Goetsch dan Davis (2017) mendefinisikan mutu sebagai memenuhi kebutuhan pelanggan untuk pertama kali dan setiap kali.

Boeing dalam Goetsch dan Davis (2017) mendefinisikan mutu sebagai memberikan produk dan jasa yang secara konsisten memenuhi kebutuhan dan harapan pelanggan. Departemen pertahanan A.S dalam Goetsch dan Davis (2017) mendefinisikan mutu sebagai melakukan pekerjaan yang benar secara tepat pada saat pertama, selalu mengusahakan perbaikan dan selalu memuaskan pelanggan.

\section{Sistem Manajemen Mutu}

MenurutmGasperz (2011) Sistem manajemen mutu merupakan sekumpulan prosedur terdokumentasi dan praktek-praktek standar untuk menajemen sistem yang menjamin kesesuaian dari suatu proses dan produk (barang/jasa) terhadap kebutuhan atau persyaratan tertentu. Kebutuhan atau persyaratan itu ditentukan atau dispesifikasikan oleh pelanggan atau organisasi. Sistem manajemen mutu mendefinisikan bagaimana organisasi menerapkan praktek-praktek manajemen mutu secara konsisten untuk memenuhi kebutuhan pelanggan dan pasar. Menurut Gasperz (2011) Terdapat beberapa karateristik umum dari sistem manajemen mutu:

a) Sistem manajemen mutu mencakup suatu lingkup yang luas dari aktivitas-aktivitas dalam organisasi modern. Kualitas atau mutu dapat didefinisikan melalui lima pendekatan utama:

(1) transcendent quality adalah suatu kondisi ideal menuju keunggulan, (2) product-based quality adalah suatu atribut produk yang memenuhi kualitas, (3) user-based quality adalah kesesuaian atau ketetapan dalam penggunaan produk (barang dan/ atau jasa), (4) manufacturing- based quality adalah kesesuaian terhadap persyaratan-persyaratan standar, dan (5) value- based quality adalah derajat keunggulan pada tingkat harga yang kompetitif.

b) Sistem manajemen mutu berfokus pada konsistensi dari proses kerja. Hal ini sering mencakup beberapa tingkat dokumentasi terhadap standar-standar kerja.

c) Sistem manajemen mutu berlandaskan pada pencegahan kesalahan sehingga bersifat proaktif, bukan deteksi pada kesalahan yang bersifat reaktif.

d) Sistem manajemen mutu mencakup elemen-elemen: tujuan (objectives), pelanggan (costumer), hasil-hasil (out-put), proses-proses (processes), masukanmasukan (inputs), 
pemasok (suppliers) dan pengukuran umpan balik dan umpan maju (measurements for feedback and feedforward). Dalam akronomi bahasa Inggris dapat disingkat menjadi: SIPOCOM- Suppliers, Inputs, Processes, Outputs, Customers, Objectives, and Meassurements.

\section{Pelayanan (Jasa/Service)}

Lovelock dalam Waluyo (2010) menyebutkan bahwa pelayanan adalah hal hal yang jika diterapkan terhadap sesuatu produk akan meningkat daya atau nilai terhadap pelanggan. Lebih lanjut Lovelock dalam Waluyo (2010) menyebutkan bahwa pelayanan yang baik membutuhkan instruktur pelayanan yang sangat baik pula. Hal yang paling penting adalah membuat setiap orang dalam organisasi berorientasi pada kualitas. Adapun unsur pelayanan yang dikemukakan oleh Syafiie (2001) meliputi tiga unsur penting dalam pelayanan, yaitu:

\section{Waktu pelayanan}

Menurut Men PAN Nomor:81 Tahun 1995, waktu pelayanan ditetapkan harus sederhana, jelas kapan selesainya, aman pengerjaannya, tepat waktu dan lancar prosesnya. Untuk itu pemerintah harus tanggap terhadap pengaduan masyarakat berupa keluhan tentang berbelit-belitnya urusan pelayanan dari aparat birokrasi. Gaspersz dalam Syafiie (2001) mengatakan bahwa, lama dan cepatnya waktu pelayanan ditentukan antara lain oleh penungguan publik terhadap penyelesaian pelayanan, kepraktisan proses pelayanan, kemudahan menjangkau setiap unit yang terkait, tersedianya informasi dan banyaknya petunjuk masyarakat.

\section{Mutu pelayanan}

Menurut SK Men PAN Nomor: 81 Tahun 1995 mutu pelayanan ditentukan oleh adanya prosedur pelayanan yang mapan, harus adanya tata cara yang umum, pertanggungjawaban pelayanan publik bila ada kendala, keadilan pelayanan secara merata, dan kesesuaian dengan peraturan perundang-undangan yang berlaku. Untuk itu pemerintah harus tanggap terhadap pengaduan masyarakat berupa keluhan tentang jelek dan buruknya hasil (Output) yang dikeluarkan aparat pelayan publik. Gaspersz dalam Syafiie (2001) mengatakan bahwa, tinggi dan rendahnya mutu pelayanan ditentukan oleh kesopanan dan keramahan pelayan publik, bebasnya dari kesalahan, kemampuan penanganan keluhan masyarakat, ketersediaan sarana dan prasarana pelayanan umum.

Biaya Pelayanan Menurut SK Men PAN Nomor: 81 Tahun 1995, biaya pelayanan ditentukan oleh ada tidaknya efisiensi, pengeluaran masyarakat yang ekonomis, penyesuaian 
pembiayaan pelayanan dengan kondisi kemampuan masyarakat, syarat-syarat pelayanan yang jelas, dan proses yang transparan. Untuk itu pemerintah harus tanggap terhadap pengaduan masyarakat berupa keluhan tentang banyaknya biaya yang dikeluarkan masyarakat dan tidak sesuainya biaya tersebut dengan ongkos yang tertera.Gaspersz dalam Syafiie (2001) mengatakan bahwa, banyak dan sedikitnya biaya pelayanan ditentukan oleh kegunaan biaya itu sendiri, cara penetapan harga, perubahan harga yang jelas, target pasar, kemungkinan diskon, kemungkinan kupon berhadiah, kerincian tata cara pembayaran, serta keterbukaan biaya yang jelas.

\section{Mutu Pelayanan}

Tjiptono dalam Buddy Ibrahim (2000) menyatakan bahwa citra kualitas atau mutu pelayanan yang baik bukanlah berdasarkan sudut pandang/ persepsi penyedia jasa, melainkan berdasarkan sudut pandang/ persepsi konsumen. Hal itu dikarenakan konsumen yang menikmati dan menggunakan jasa yang disediakan oleh pelayanan tersebut. Untuk kualitas (mutu pelayanan) terdapat kriteria karateristik menurut Len Berry, Pasaruraman, dan Valerie Zeithaml dalam Buddy Ibrahim (2000) yang dipaparkan sebagai berikut:

a) Reability: konsistensi dalam kinerja dan ketahanannya; kinerja benar sejak awal pertama kali; menepati janji dan akurat dalam spesifikasi; sesuai dengan iklan dan label,

b) Responsiveness: tanggap terhadap klaim/ protes konsumen; kesiapan karyawan memberikan service pada waktu yang diperlukan; cepat bereaksi terhadap perubahan lingkungan misalnya teknologi, peraturan, perilaku konsumen,

c) Competence: menguasai keterampilan dan pengetahuan yang memadai untuk memberikan servis yang diperlukan.

d) Access: kemudahan pendekatan dan akses; waktu tunggu pendek,

e) Cortesy: sopan santun; respek, perhatian, tulus, dan keramahan dari personil/ karyawan service, sabar mendengarkan keluhan pelanggan,

f) Communication: pemberitahuan informasi kepada para konsumen dalam bahasa yang dipahami oleh konsumen; mendengarkan suara konsumen; menyesuaikan bahasa kepada kebutuhan konsumen yang berbeda.

g) Credibility: kepercayaan, keandalan, kejujuran; reputasi perusahaan/organisasi; karateristik pribadi dari karyawan perusahaan,

h) Security: bebas dari bahaya, resiko, atau keraguan; keamanan fisik; keamanan finansial; kerahasiaan. 
i) Understanding the customer: memahami konsumen, berusaha mengerti kebutuhan konsumen; belajar memahami kebutuhan konsumen yang spesifik; memberikan perhatian pribadi; memperhatikan langganan yang baru maupun regular dan royal,

j) Assurance: memiliki sumber daya manusia dan teknologi serta fasilitas untuk memberikan jaminan memenuhi kebutuhan konsumen dengan jasa purnajual jangka panjang, bukan sesaat saja sewaktu menyerahkan barang.

k) Tangibles: bukti fisik adanya jasa (service); fasilitas fisik, penampilan personil/karyawan; perangkat (tools) untuk menyediakan jasa (service); pelayanan jasa dengan kemudahan dan efisien bagi konsumen.

\section{Kepuasan Pelanggan}

Kepuasan pelanggan berjalan berbarengan dengan ketidakpuasan. Artinya respons pelanggan terhadap evaluasi dan ketidaksesuaian yang dirasakan antara harapan sebelumnya dan kinerja aktual produk yang dirasakan setelah pemakaiannya. Jadi kepuasan adalah suatu tanggapan emosional yang dirasakan oleh pelanggan pada saat mereka menikmati pengalaman menggunakan atau mengonsumsi produk/jasa. Dengan demikian kepuasaan pelanggan adalah evaluasi pasca pembelian, dimana alternative yang dibeli minimal sama atau melebihi harapan pelanggan.

Berdasarkan pengertian ini, maka kepuasan pelanggan adalah tingkat perasaan seseorang setelah membandingkan kinerja atau hasil yang ia rasakan dibandingkan dengan harapannya. Beberapa pengertian kepuasan pelanggan menurut para ahli:

a. Respons atau tanggapan konsumen mengenai pemenuhuan kebutuhan. Kepuasan merupakan penilaian mengenai ciri atau keistimewaan produk atau jasa, atau produk itu sendiri, yang menyediakan tingkat kesenangan konsumen berkaitan dengan pemenuhan kebutuhan konsumsi konsumen (Zeithaml dan Bitner dalam Rangkuti, 2000).

b. Kepuasan konsumen adalah sejauh mana anggapan kinerja produk memenuhi harapan pembeli. Bila kinerja produk lebih tinggi ketimbang harapan pelanggan,maka pembelinya merasa puas atau amat gembira (Kotler dan Amstrong dalam Rangkuti, 2000).

c. Keadaan emosional, reaksi pasca pembelian dapat berupa kemarahan, ketidakpuasan, kejengkelan, kegembiraan, atau kesenangan (Lovelock, 2000). 


\section{HASIL PENELITIAN DAN PEMBAHASAN}

Data dan hasil yang diperoleh di lapangan melalui analisis dokumen dokumentasi yaitu mempelajari data-data, laporan dan arsip yang berhubungan dengan penelitian.

Berdasarkan penelitian yang dilakukan oleh penulis yaitu tentang Sistem Manajemen Mutu ISO seri 9000 yang di terapkan Indonesia Dalam Peningkatan Mutu Produk/ Pelayanan dan Kepuasan Pelanggan di Pasar Internasional Adapun fokus dari penelitian ini adalah sebagai berikut:

\section{Menetapkan suatu komitmen Indonesia untuk pelaksanan ISO seri 9000 di Indonesia}

Berdasarkan hasil peneltian yang dilakukan, Indonesia telah mengadopsi aturan ISO seri 9000 kedalam kebijakan pemerintahan terutama bidang ekspor . Dapat diketahui bahwa pemenuhan persyaratan pada Sistem Manajemen Mutu ISO seri 9000 yaitu fokus pada pelanggan, kepemimpinan, pelibatan orang, pendekatan proses, pendekatan pada sistem manajemen, perbaikan berkelanjutan, pengambilan keputusan berdasarkan fakta, dan hubungan pemasok yang saling menguntungkan. Artinya dalam menjaga terjaminnya mutu pelayanan yang baik bagi Pasar Internasional, Indonesia sangat berkomitmen untuk tetap menjaga kualitas pelayanan yang diberikan, hal itu terlihat pada seluruh kegiatan-kegiatan yang ada memiliki prosedur tertulis dengan membuat Standar Operasional Prosedur (SOP) pada tiap bagian struktur Perusahaan sehingga proses- proses

yang di Operasional perusahaan berjalan secara konsisten. Maka dapat dikatakan bahwa pelayanan yang diberikan mempunyai standar mutu yang baik bagi pelanggan karena pimpinan sangat bertanggung jawab dalam menentukan, melaksanakan, dan menjaga sistem manajemen mutu ISO 9000.

\section{Mendefinisikan Struktur Organisasi dan Tanggung Jawab}

Berdasarkan hasil peneltian literature, dapat diketahui bahwa dalam peran masingmasing bagian pada Badan/ Organisasi seperi BSN, KAN, DSN telah di atur di dalam job description yang dimana telah diuraikan secara jelas mengenai fungsi, tugas-tugas, tanggung jawab, wewenang kondisi kerja serta aspek-aspek lainnya dan telah terdapatnya suatu kejelasan tentang apa-apa yang harus dikerjakan oleh Pegawai Perusahaan . Job description Pegawai Perusahaan dijadikan tujuan atau target bagi pegawai karena adanya kejelasan fungsi dan tugas mereka dalam meelakukan pekerjaan dan menjadi kriteria yang dapat mengukur keberhasilan pegawai. Job description yang ada juga telah memberikan pengaruh pada hasil kinerja pegawainya hal itu ditunjukkan dengan peningkatan mutu Produk 
Perusahaan Hal ini menunjukkan bahwa pelaksanaan tugas-tugas atau pekerjaan tersebut telah berdasarkan pada tugas dan fungsi pegawai daerah secara umum yang diatur dalam UU No.43 Tahun 1999 tentang manajemen kepegawaian yang merupakan keseluruhan upaya pemerintah dalam meningkatkan efisiensi, efektivitas, dan derajat profesionalisme pelaksana tugas, fungsi serta kewajiban.

\section{Menciptakan Kesadaran Kualitas atau Mutu (quality awareness) Pada Semua Tingkat Dalam Organisasi}

Berdasarkan hasil penelitian literature yang Pemerintah Indonesia diwakili oleh BSN/ KAN, DSN dapat diketahui bahwa dalam upaya peningkatan mutu Produk setiap saat selalu mensosialisasikan Sistem Manajemen Mutu ISO seri 9000 pada seluruh pegawai serta melakukan kegitan pelatihan yang bertujan untuk meningkatkan mutu pelayanan dan kinerja pegawai menjadi tenaga professional yang dapat menunjang keberhasilan Perusahaan tersebut. Artinya dalam hal ini keseluruhan proses mengenai peningkatan mutu pada Sistem Manajemen Mutu ISO seri 9000 Perusahaan- Perusahaan telah dipahami dan dimengerti oleh seluruh staf atau pegawai yang ada baik tentang prinsip-prinsip serta persyaratan dalam ISO seri 9000, sehingga dalam proses menjalankan Sistem Manajemen Mutu ISO seri 9000 seluruh pegawai tidak mengalami hambatan ataupun kesulitan mengenai aturan-aturan yang di atur di dalam ISO seri 9000 tersebut.

\section{Mendokumentasikan Aktivitas Terperinci Dalam Prosedur Operasional dan Prosedur}

\section{Terperinci}

Berdasarkan hasil peneltian yang dilakukan Perusahaan-perusahaan yang mendapat sertifikasi dapat diketahui bahwa dokumentasi dalam Sistem Manajemen Mutu ISO seri 9000 di Indonesia sudah sesuai dengan persyaratan ISO itu sendiri. Terlihat jelas bahwa adanya pengelolaan sistem dokumentasi yang baik. Setiap dokumentasi sangat jelas dilakukan karena di dalam proses dokumentasinya tiap-tiap dokumen yang akan di dokumentasikan telah ada pembagian yang diatur berdasarkan jenis dan bentuk dokumennya dan dalam pendokumentasiannya di periksa dan disahkan oleh pejabat yang berwenang, sehingga halhal yang berkaitan dengan dokumentasi dilakukan dengan jelas, dapat diidentifikasi dan diperoleh kembali dengan mudah serta dapat dideteksi sejak awal apabila terdapat ketidaksesuaian antara kegiatan yang direncanakan terhadap hasil kegiatan yang dilakukan. 


\section{Meninjau Ulang dan Audit Sistem Manajemen Mutu}

Berdasarkan hasil peneltian yang dilakukan, dapat diketahui bahwa audit internal yang dibuat memang dilaksanakan sepenuhnya dengan baik dan sekaligus dapat memeriksa sistem yang dipakai dan merupakan sarana yang efektif untuk mencapai tujuan Perusahaan karena audit dilaksanakan oleh personel yang tidak terkait (independen) dengan yang mempunyai tanggung jawab langsung dengan kegiatan yang diaudit dan telah berpengalaman atau mendapat pelatihan teknik audit internal.

1. Sementara itu pada tingkat kepuasan pelanggan melalui gambaran umum hasil pencapaian produk produk kita yang di terima di pasar internasional menjadi meningkat ${ }^{2}$.

\begin{tabular}{lllll}
\hline NO & Tahun & $\begin{array}{l}\text { Jumlah Perusahaan Sertifikat ISO } \\
\text { seri } 9000\end{array}$ & Keterangan \\
1 & $1992-1997$ & 430 & Meningkat $350 \%$ \\
2 & 1999 & 1.525 & Meningkat $70 \%$ \\
3 & 2001 & 2.410 &
\end{tabular}

Sumber: Warta Standarisi, Badan Standarisasi Nasional

Berdasarkan data yang diperoleh Indonesia dalam Sistem Manjemen Mutu ISO seri 9000 telah berhasil meningkatkan kepuasan pelanggan mengenai hal dalam pemenuhan keinginan dan kebutuhan pelanggan bagi pengguna jasa pelayanan. Hal ini sejalan dengan prinsip Sistem Manajemen Mutu ISO seri 9000 bahwa tiap organisasi harus mampu memenuhi dan berusaha melebihi harapan dan keinginan pelanggan sesuai dengan prinsip ISO seri 9000 .

\section{Kualitas Pelayanan (service quality)}

Kualitas pelayanan yang ada di lakukan oleh Indonesia sudah sangat baik, dan memberikan rasa puas sesuai dengan apa yang diharapkan oleh pelanggan. Pelanggan mendapatkan pelayanan dengan mudah, dari segi kenyamanan pelanggan telah terpenuhi dengan keramahan dan kesopanan petugas dalam memberikan pelayanan, serta segi waktu pelayanan tidak ada terdapat waktu tunggu yang lama bagi pelanggan dalam menerima pelayanan. 


\section{Kualitas Produk (quality product)}

Kualitas Produk yang di eksport oleh Indonesia jarang sekali mengalami refusal action atau penolakana di sebabkan kurang memenuhi standar yang ada di ISO seri 9000. Jika pun ada Perusahaan bersedia menangani keluhan pelanggan hingga tuntas mengenai produk jasa.

\section{KESIMPULAN DAN SARAN}

\section{Kesimpulan}

Sistem Manajemen Mutu ISO seri 9000 dalam Peningkatan Mutu di Indonesia di respon baik oleh perusahaan perusahaan, ini dibuktikan dengan meningkatnya jumlah perusahaan yang mendapatkan sertifikasi ISO seri 9000. Hal tersebut dapat dilihat dari berbagai indikator, yaitu:

1. Menetapkan Suatu Komitmen Pemerintah, Perusahaan (top management commitment).

Standar Operasional Prosedur (SOP) pada tiap bagian struktur organisasi.

2. Dengan di Adopsinya ISO seri 9000 menjadi SNI 9000 untuk Perusahaan perusahaan di Indonesia.

3. Mendefinisikan Struktur Organisasi dan Tanggung Jawab, dalam menjalankan fungsi dan tugas mengingat adanya pembagian peran masing-masing bagian yang ada di description yang dimana menguraikan secara jelas mengenai fungsi, tugas-tugas, tanggung jawab, wewenang kondisi kerja serta aspek-aspek lainnya dan telah terdapatnya suatu kejelasan tentang apa-apa yang harus dikerjakan oleh pegawai dalam melakukan pekerjaannya.

4. Menciptakan Kesadaran Kualitas atau Mutu (quality awareness) Pada Semua Tingkat dalam Perusahaan dan mengadakan pelatihan untuk peningkatan kemampuan pegawai.

5. Mendokumentasikan Aktivitas Terperinci Dalam Prosedur Operasional dan Prosedur Terperinci, dokumentasi dalam Sistem Manajemen Mutu ISO seri 9000.

6. Meninjau Ulang dan Audit Sistem Manajemen Mutu, bahwa audit internal yang dibuat dilaksanakan sepenuhnya dengan baik dan sekaligus dapat memeriksa sistem yang dipakai dan merupakan sarana yang efektif .

7. Kualitas Produk, bentuk dalam pemenuhan kebutuhan pelanggan dan selalu mamahami apa yang dibutuhkan oleh pelanggan serta bersedia menangani keluhan 
pelanggan hingga tuntas mengenai produk jasa yang diberikan serta petugas memahami dan menguasai semua bentuk produk jasa diberikan kepada pelanggan.

\section{Saran}

Adapun saran-saran yang diberikan oleh penetian adalah sebagai berikut:

1. Dalam melakukan audit, auditor harus berusaha untuk tetap meningkatkan kinerjanya agar audit mutu internal dapat mencapai hasil yang optimal. Auditorsebaiknya harus tetap terus menambah pengalaman kerja khususnya terkait dengan manajemen proses pada semua bagian, mengikuti berbagai pelatihan mengenai audit mutu internal, mengikuti seminar atau konferensi yang terkait. Dengan sistem manajemen mutu, melakukan bimbingan dan konsultasi dengan sistem manajemen mutu, serta terus dapat menambah pengetahuan serta informasi dari berbagai media.

2. Pemerintah perlu lebih sering mensosialisasikan proses penerapan Sistem Manajemen Mutu ISO seri 9000 serta keuntungan yang diperoleh organisasi dengan mengadopsi Sistem manajem Mutu ISO seri 9000.

3. Sebaiknya pada proses penerapan Sistem Manajemen Mutu ISO seri 9000 dibentuk tim khusus ISO, kemudian dibuat struktur organisasinya dengan tugasnya masingmasing agar proses manajemen berjalan dengan efektif dan efisien.

\section{REFERENSI}

Arikunto. 2012. Metodologi Penelitian Suatu Pendekatan Proposal. Jakarta: PT. Rineka Cipta.

Chatab, Nevizond 2017. Mendokumentasi Sistem Mutu ISO seri 9000.Andi Yogyakarta, Yogyakarta.

David L. Goetsch dan Stanley B. Davis. 2017. Pengantar Manajemen Mutu 2. Jakarta: PT. Prenhalindo.

Dimas Wicaksono, Bayu dan Sri Langgeng Ratnasari. 2018. Jurnal_ Determinasi Komunikasi,Motivasi dan Lingkungan Kerja terhadap Kinerja Karyawan di Perusahaan Umum ( PERUM) Bulog Sub-Drive Kota Batam.

Freddy, Rangkuti. 2011. Customer Service Satisfaction \& Call Center Berdasarkan ISO 9001. Jakarta: Gramedia Pustaka Utama.

Gaspersz, Vincent. (2011). Total Quality Management. Jakarta: Gramedia Pustaka Utama. Ibrahim, Buddy. (2010). TQM (Total Quality Management): Panduan Untuk Menghadapi Persaingan Global. Jakarta: Djambatan. 
J, Lexy Moleong. 2012. Metodelogi Penelitian Kualitatif. Bandung: PT. Remaja Rosdakarya. Miles Matthew B. A. Michael Hubberman. 2012. Analisis Data Kualitatif. Penterjemah Tjejep R. Rohidi. Jakarta: UI Press.

Rahman, A. 2011. Sistem Politik Indonesia. Yogyakarta: Graha Ilmu.

Sugiyono. 2010. Metode Penelitian Kuantitatif, Kualitatif dan R \& D. Bandung: Alfabet.

Supranto. 2010. Perilaku Konsumen dan Strategi Pemasaran Untuk Memenangkan Persaingan Bisnis. Jakarta: Mitra Wacana Media.

Syafiie, Inu Kencana. 2011. Manajemen Pemerintahan. Bandung: Pustaka Reka Cipta.

Waluyo. 2010. Manajemen Publik (Konsep, Aplikasi dan Implementasinya Dalam Pelaksanaan Otonomi Daerah. Bandung: Mandar Maju.

Yayat M. Herujito. 201). Dasar-dasar Manajemen. Jakarta: Grasindo. 